\title{
THE SOVIET UNION AND THE UNITED NATIONS*
}

\author{
RICHARD N. GARDNER $\dagger$
}

After a recent speech by a State Department official on U.S. policy toward the United Nations, someone got up in the question period and declared: "You have argued that the United Nations serves the national interest of the United States and other countries of the free world. But how, according to your own analysis, can it also be said to serve the interest of the Soviet Union?"

This perceptive and difficult question is asked in one form or another in all serious discussions of the United Nations. To help find an answer, it may be useful to take a brief look at the record of Soviet participation in the United Nations, and at the prospects for the future suggested by recent developments in Soviet foreign policy.

\section{The ReCORD}

When we look at the record of the Soviet Union in the United Nations, we see a striking contrast between word and deed, between Communist ideology and Charter principle. In word, the Soviet Union has often found it expedient to support the United Nations. In I947, for example, André Vyshinsky, then Deputy Minister for Foreign Affairs, had this to say:

The policy of the U.S.S.R. with regard to the United Nations calls for strengthening that body, extending and reinforcing international cooperation, unfaltering and consistent observance of the charter and the implementation of its principles.

The Soviets have hardly lived up to these fine words. Why not? Putting it bluntly, the ideological "baggage" that the Soviet Union brought with it into the United Nations has made it difficult, if not impossible, to accept the full obligations of membership. Indeed, it is hard to escape the conclusion that there is a fundamental incompatibility at almost every point between traditional Communist doctrine and the principles of the U.N. Charter:

-Communist doctrine looks forward to a monolithic world of Communist states. The United Nations Charter looks forward to a world of diversity, where each country can develop differently in accordance with the different characteristics and aspirations of its people.

- This article is based on a chapter in the author's book, IN PURsurt of Wordd Order: U.S. ForeigN Policy and International Organizations, published by Frederick A. Praeger, Inc.

+B.A. I948, Harvard University; LL.B. 195I, Yale Law School; Ph.D. I954, Oxford University. Deputy Assistant Secretary of State for International Organization Affairs. Former Professor of Law, Columbia University. Author, Sterling-Dollar Diplomacy: Anglo-American Coliaboration in the Reconstruction of Multilateral Trade (I956); New Directions in U.S. Foreign Economic Polict (1959). 
- Communist doctrine seeks to build a Communist world through coercion. The United Nations Charter seeks to assure a world of free choice.

-Communist doctrine sees a world divided into hostile camps-Communist and Capitalist. Even the slogan "peaceful coexistence" was defined by Khrushchev as " $\mathrm{n}$ form of intensive economic, political, and ideological struggle" whose only outcome can be the triumph of Communism and the burial of Capitalism. The Charter sees one world in which the interests that unite nations are stronger than the interests which divide them. As Alexander Dallin has put it, the Soviet Union is "a state with a 'two-camp' world view trying to operate in a 'one-world' organization."'

- Communist doctrine-like all totalitarian doctrine-distrusts international organizations that the Communist leadership cannot control. The U.N. Charter establishes an international organization beyond the control of any state or party.

- Communist doctrine denies the possibility of impartial men rendering disinterested judgment in the service of international institutions. The United Nations was founded on this very assumption.

-Communist doctrine and the narrow interests of the Communist elite demand a closed society in which the population is sealed off from exposure to alien ideas. The United Nations looks to an open world in which the free play of ideas can build a community of values and attitudes.

But we do not need further illustrations of the clash between Communism and the Charter on the level of principle. What is more relevant is the collision between the Soviet Union and the United Nations in actual practice. In two decades of U.N. history, this collision has occurred in eight principal areas:

r. Communist Coercion. The most obvious area in which Soviet policy has collided with the Charter has been the systematic attempt of the Soviet Union to promote its political and ideological objectives by use of force. This collision was not unprecedented. In 1939, the Soviet Union had been expelled from the League of Nations only a few years after its admission for its unprovoked invasion of Finland. Those who hoped that the creation of the United Nations would bring fundamental changes in Soviet foreign policy were quickly disappointed. Indeed, many of the major crises that have beset the United Nations since its inception-in Iran, Greece, Korea, Hungary-have resulted from the attempt of the Soviet Union to impose its system by force in violation of the U.N. Charter. The fact that the Soviet Union has found it necessary to cast more than roo vetoes in the Security Council gives one measure of the extent of the problem.

The U.N. operation in the Congo provides a recent example of how the United Nations stood in the way of the historic Soviet thrust for world domination. The Soviet Union counted on filling the power vacuum created by the withdrawal of colonial rule in Africa and elsewhere. The Congo offered a particularly good opportunity: here was the strategic key to sub-Saharan Africa, possessed of great

\footnotetext{
${ }^{1}$ Aiexander Dallin, The Soviet Union at the United Nations 6 (1962).
} 
wealth, in a chaotic condition after independence. The Soviet Union voted for the initial Security Council resolutions on the Congo-perhaps in the mistaken belief that the United Nations would confine itself to preventing the re-entry of Belgian troops. It soon began to oppose the operation when it became clear that the United Nations would act to protect the new Congolese nation against the intervention of outside forces-including those of the Soviet Union-and to preserve a unified state. By controlling the key airfields and other points of entry into the Congo, the United Nations was able to prevent the extensive intrusion of Soviet personnel against the wishes of the Central Government and thus helped to avert the transformation of that country into a cold war battleground. It was inevitable that the United Nations' attempt to implement its mandate to protect the Congo's territorial integrity and political independence would provoke the violent opposition of the principal member that was working in the other direction.

2. Constitutional Development. The Soviet Union has always seen the U.N. Charter essentially as a contract between rival states rather than as a constitution capable of organic growth in the service of a world community. The collision between the pursuit of Communist goals by coercion and the United Nations' defense of national independence based on free choice has with growing frequency been manifested in constitutional arguments about the interpretation of the U.N. Charter.

The central element in the controversy has been the authority of the United Nations to carry on peacekeeping activities that could frustrate the pursuit of Communist aims. The Soviet Union has insisted on the so-called "principle of unanimity" -the doctrine that no peacekeeping action can be undertaken except through agreement at every step of the way of all five Permanent Members of the Securty Council.

The overwhelming majority of U.N. members have refused to accept so restrictive an interpretation of U.N. power. Through the Uniting for Peace Resolution, they established procedures by which the General Assembly could exercise its residual authority contained in the Charter to deal with threats to international peace and security in the event that the Security Council was unable to carry out its primary responsibility in this field. And in instances such as the Congo crisis, when the Security Council initially voted a peacekeeping operation, they supported the broad exercise of authority by the Secretary-General to assemble peacekeeping forces through voluntary arrangements with individual members. The refusal of the Soviet Union to accept the legality of these procedures and of the operations they made possible thrust the United Nations into its most serious constitutional crisis.

3. Financing. Directly related to the conflict between the Soviet Union and the United Nations over constitutional interpretation has been the conflict over U.N. financing. In the face of the veto power of Security Council members, the United Nations had no legal right to require that the Soviet Union supply troops or logistic support for operations it opposed, but it did have the legal right to assess the Soviet Union for its fair share of the cost of peacekeeping forces voluntarily supplied by others. The exercise of this right in the Middle East and Congo operations led to 
the clash over Article Ig of the Charter, which provides for the loss of vote in the General Assembly of any country more than two years behind in its total assessments.

The Soviet position in this matter has been very clear: It will not pay for U.N. activities it does not like-at least in so far as the expenditures support functions it regards as beyond the normal administrative activities of the organization. As a result, the Soviet Union has even gone so far as to declare its intention not to pay that portion of its regular budget assessment which goes for the U.N. field service, the Korean cemetery, and the repayment of interest and principal on the U.N. bonds. Obviously, the collision between the Soviet Union and the United Nations on financial matters is but another manifestation of the Soviet Union's restrictive view of the U.N. Charter, and of its determination to pursue its foreign policy goals free of any possible interference from the independent activity of international organizations.

4. International Civil Service. Still another manifestation of the Soviet attempt to hamstring the independent operation of the United Nations has been the conflict between Soviet and Charter concepts of the international civil service. This conflict came to a head in I96r, when the Soviet Union mounted a frontal assault on the independence of the U.N. executive. Having failed to paralyze the United Nations through the exercise of its veto in the Security Council and its refusal to pay its peacekeeping assessments, the Soviet Union unveiled its Troika demand. This proposal to replace the Secretary-General by three Secretaries-General (representing the Communist states, the so-called Western states, and the so-called uncommitted states) would have given the Soviet Union the very veto over U.N. operations that it had failed to achieve by others means. This fact was very clearly perceived by the other U.N. members, and they rejected the Troika overwhelmingly.

Article roo of the United Nations Charter represents the most modern expression yet given to the concept of the international civil service:

I. In the performance of their duties the Secretary-General and the staff shall not seek or receive instructions from any government or from any other authority external to the Organization. They shall refrain from any action which might reflect on their position as international officials responsible only to the Organization.

2. Each Member of the United Nations undertakes to respect the exclusively international character of the responsibilities of the Secretary-General and the staff and not to seek to influence them in the discharge of their responsibilities.

The Soviet Union has accepted this article neither in principle nor in practice. At the time of the Troika controversy, Walter Lippmann wrote that Khrushchev told him he "would never accept a single neutral administrator. Why? Because, he said, while there are neutral countries, there are not neutral men. You would not accept a Communist administrator and I cannot accept a non-Communist administrator."

In expressing these views, Khrushchev was not developing any new Soviet policy.

3 "Khrushchev to Lippmann-Face to Face, No. 1," N.Y. Herald Tribune, April 17, 1961, p. I, col, 1; p. 2, col. 4 . 
His remarks are consistent with the Soviet Union's traditional philosophy toward the international civil service going back to League of Nations days. The concept that an individual from any country can serve an international institution in a disinterested manner rather than carry out the policies of his nation, party, or class is alien to traditional Communist doctrine. Indeed, the attitude that the Fascist countries took on the same issue in the League of Nations days indicates that the concept is equally incompatible with any totalitarian philosophy.

Soviet practice reflects precisely this traditional philosophy. The Soviet Union normally hand-picks its senior nominees for the U.N. Secretariat from the Soviet Foreign Ministry and does not permit direct recruitment of U.N. staff within the Soviet Union. It does not permit its citizens to undertake long-term careers with the United Nations but rather rotates them in and out of the Secretariat every two or three years. Most important of all, it does not permit its citizens to serve as truly independent members of the Secretariat. Newspaper accounts of the senior Soviet official in the Secretariat passing notes to the Soviet representative on the Security Council and of the espionage activities conducted in the United States by Soviet citizens in the Secretariat have dramatized the problem for all who are willing to face the facts. It is only in technical and relatively non-political assignments with the United Nations and the specialized agencies that Soviet citizens have seemed to live up fully to their responsibilities under the Charter.

The Troika demand was defeated. But the battle still goes on. Continued vigilance is necessary to protect the international civil service from these Soviet practices. Moreover, U.N. agencies continue to be threatened by "creeping Troika"-the simplistic concept not confined to the Communist bloc that the world is divided into three groups and that every individual must be regarded as the servant of one of these groups.

5. International Adjudication. The Soviet Union has consistently resisted the settlement of disputes by international courts or arbitral tribunals. It was obliged to accept the statute of the International Court of Justice as the price for membership in the United Nations. But it never accepted the compulsory jurisdiction of the Court-i.e., the obligation to submit to the jurisdiction of the Court in an international legal dispute at the behest of another country accepting the same obligation. By itself, of course, this fact would not be conclusive: A large number of nonCommunist countries have also declined to accept the Court's compulsory jurisdiction, and some of the countries that have accepted it in principle-such as the United States-have attached important qualifications. What is more significant is that the Soviet Union has steadfastly refused to submit individual cases to the Court. And it has usually declined to accept provisions in bilateral or multilateral agreements calling for compulsory jurisdiction of the Court in disputes over their interpretation.

The Soviet Union has also consistently opposed requests by U.N. organs for advisory opinions from the International Court. In the assessments case, however, the Soviet Union did participate for the first time in oral argument before the Court- 
in the person of Gregory I. Tunkin, the Legal Adviser of the Soviet Foreign Ministry. Having participated, the Soviet Union nevertheless did not consider itself estopped from continuing to challenge the validity of the advisory opinion as accepted by the General Assembly.

6. Economic and Social Cooperation. The Soviet Union has taken a highly restrictive view of the economic and social as well as the political activities of international organizations. At the outset of the United Nations, indeed, the Soviet attitude was even more negative on the economic than on the political side. In his opening speech at the San Francisco Conference in 1945, Foreign Minister Molotov emphasized the need for an "international security organization" and failed entirely to mention any economic and social functions.

Soviet policy in the early years of the United Nations reflected this negative attitude toward the development of international organization in the economic and social field. The Soviet Union turned up at the Bretton Woods Conference at the last moment but failed to join either the International Bank or the International Monetary Fund. It declined to participate in the drafting of the Charter for the International Trade Organization despite the elaborate state-trading provisions which were included to facilitate its membership. It never adhered to the General Agreement on Tariffs and Trade.

The pattern was the same with other international organizations in functional and technical fields. Of the Big Five nonfinancial Specialized Agencies, the Soviet Union never joined the Food and Agriculture Organization or the International Civil Aviation Organization, and for some years it refrained from membership in UNESCO, the International Labor Organization, and the World Health Organization. While it has not failed to exploit meetings of these institutions for propaganda purposes, its participation in their field operations has been marginal, and the Soviet Union has consistently opposed substantial increases in their budgets and programs.

The pattern has been the same in the case of voluntary programs of the United Nations. The Soviet Union at first declined to participate in the Expanded Program of Technical Assistance when it was created in 1949; although it joined the program in 1953 and also joined the U.N. Special Fund when it was created in 1959, its participation in both institutions has been unenthusiastic. In 1964 , the Soviet contribution to the two programs amounted to $\$ 4$ million out of nearly $\$ 150$ millionsomething under three per cent of the total-as compared to its seventeen per cent share of the regular budget. Even this modest contribution is paid in rubles, the employment of which is subject to so many restrictions that the United Nations has difficulty in making full use of them. Soviet experts participating in these programs in 1963 totaled only 90 out of 2,634 .

The niggardly Soviet financial contribution to the United Nations' economic and social work scarcely bears out Soviet claims of superior economic performance. Observers at the U.N. General Assembly are always amused to hear Soviet delegates boast in the Economic Committee that the Soviet Union will soon overtake the 
United States in gross national product and living standards, while pleading in the Budgetary Committee that its stringent economic circumstances and balance of payments difficulties require modest contributions to the United Nations.

It is not difficult to explain why executive action by international agencies should be anathema to the Soviet Union in economic as well as political affairs. Traditional Soviet policy has sought to maintain the maximum freedom of action in both areas. Only in recent years has the Soviet Union begun to emerge from a policy based on economic autarky to play an increasingly active role in international economic relations. It is clearly determined to play that role for high political stakes-to use trade and aid as political and ideological instruments. So far, there has been little room in such a strategy for large-scale cooperative programs through international organizations in trade and aid.

The negative attitude toward economic cooperation has been reflected in another area of U.N. activity-the promotion of human rights. The Soviet bloc joined the Union of South Africa in 1948 in abstaining in the vote on the Universal Declaration of Human Rights. In the early years of the United Nations, it took a wholly negative and defensive posture in the discussion of human rights questions. While later it began gradually to exploit the propaganda opportunities in this field-as it did in economic relations - its objection to the development of any executive functions for the United Nations continued unabated. The Soviet Union has consistently opposed any proposals for the international implementation of human rights standards, even comparatively modest measures involving fellowships, research, and the reporting of national human rights practices. It has resisted the implementation provisions in the draft Human Rights Covenants for bringing disputed situations to a Human Rights Committee or to the International Court. As might be expected, it has also opposed any role for nongovernmental organizations in the submission of information in the field of human rights.

7. Information Activities. It is implicit in the Charter of the United Nations that the informed citizenry in member states, knowledgeable about the purposes and activities of the United Nations, will encourage the responsible behavior of their governments in conformity with Charter standards. This assumption has considerable validity in many countries of the free world. In the United States, for example, public opinion is highly sensitized to activities of the United Nations. Thanks in part to the work of the United Nations Association of the United States of America, ${ }^{3}$ information about the United Nations and other international organizations in universities, high schools, and adult organizations is extensive and well presented. Most important, the work of this organization and widespread coverage of events in New York by the press, radio, and television insure that those who determine U.S. policy on issues before the United Nations are conscious at every step of the way of the pressures of American opinion. While there is a powerful

\footnotetext{
${ }^{3}$ The new private organization resulting from the merger of the American Association for the United Nations and the U.S. Committee for the United Nations.
} 
anti-U.N. lobby, there is also an important constituency pressing for affirmative U.S. policies in the political and economic work of the organization.

No such influence affects Soviet policy in the United Nations. Few U.N. activities take place in the Soviet Union. The Soviet equivalent of the United Nations Association is largely ornamental and does not act independently of the government to influence public attitudes. United Nations documents are not readily available to Soviet citizens. The U.N. Information Center in Moscow is located in three rooms of an apartment house in a modest residential section, and foreign visitors describe it as one of the loneliest places to be found in the city. ${ }^{4}$ There is only perfunctory mention of the United Nations in the schools and only limited and self-serving coverage of U.N. activities in the Soviet press.

8. Peacekeeping and Disarmament. A central element in the disarmament plans advanced by the United States and other Western countries has been the building up of the United Nations as a peacekeeping agency-specifically, the creation of a U.N. peace force and more effective procedure for pacific settlement of disputes. The reason for this is obvious: Nations will never be willing to eliminate or even radically reduce their arms until they have some other way to maintain their security and protect their vital interests.

Here again, hopes for building up the United Nations as an executive agency have run squarely into Soviet opposition. While the Soviet Union has sometimes paid lip service to the concept of a U.N. peacekeeping role, its proposals on this subject have been devoid of substance. Moreover, Soviet bloc representatives at the Geneva disarmament conference have depreciated the peacekeeping issue as an undesirable distraction from the subject of disarmament.

\section{II}

\section{Recent Trends}

One cannot fail to be impressed with the consistency of Soviet behavior on fundamental constitutional issues during two decades of participation in the United Nations. Yet Soviet tactics have not been static. They have changed with the general change in tactics of Soviet foreign policy that became evident in the early I950s and are generally associated with the death of Stalin.

During the last decade, Soviet diplomacy in the United Nations has become more sophisticated. The Soviets recognized that the old hard line was not working and that a softer approach might yield political dividends. And they were encouraged to believe that the influx of newly independent countries from Africa and Asia would change the balance of forces in the United Nations in their favor. In recent years, Soviet publications have ceased to speak of "automatic majorities" of Western nations in the United Nations and have suggested instead that on key issues, the United States and its allies will eventually be reduced to a minority position.

"Dazirs, op. cit. stupra note I, at 92-93. 
The fundamental element in the change of Soviet U.N. tactics was the recognition that the new nations arriving in the United Nations offered a tempting and available opportunity to influence important and, hopefully, susceptible political figures. Anticolonialism, disarmament, and trade became the central themes in the Soviet Union's new approach which culminated in Premier Khrushchev's dramatic visit to the $15^{\text {th }}$ General Assembly in I960. The more sophisticated Soviet policy was also evident in some of the Specialized Agencies and in economic forums such as the Economic and Social Council. Perhaps the most dramatic example of the shift in the Soviet line came in the field of trade. The same nation that had ignored international economic problems entirely at San Francisco and had boycotted the negotiations on the ITO and GAT'T suddenly turned around in the mid-I950s and started calling for an International Trade Organization with a broad mandate to promote and regulate international commerce, particularly between countries with different economic systems.

Yet the shifts on all these issues were essentially tactical ones. The Soviet Union had come to appreciate the possibilities of the United Nations as a propaganda vehicle, but it continued its negative approach to U.N. operations. During his famous visit to the I5th General Assembly, Khrushchev declared:

Experience of the work of the United Nations has shown that this body is useful and necessary, because in it are represented all the States which are called upon to solve, through negotiation and discussion, the pressing issues of international relations so as to prevent them from reaching a point where conflict and wars might break out. That is the positive aspect of the work of the United Nations. That, indeed, constitutes the main purpose of the creation of the United Nations.

Notably missing from this Soviet benediction of the United Nations was any reference to its function as an operating agency-as an instrument for building free nations and keeping the peace. This is not surprising. The Communists have been concerned by the prospect that the United Nations might achieve a greater operational capability to carry out a Charter full of dangerous thoughts about freedom of choice for all men-a capability that could bury the Communist version of fistory without the necessity of a major war.

\section{III}

\section{THE OUTIOOK}

This record of Soviet participation in the United Nations is not encouraging. But it is no occasion for hopelessness or despair. We must not fall into the habit of thinking that nothing can be done to strengthen the United Nations as a force for peace and welfare without the cooperation of the Soviet Union. The whole history of the United Nations-in Korea, the Congo, and the Middle East, in technical cooperation and aid to less developed countries-proves that the contrary is the case. This will continue to be so as long as the United States and other free nations work 
together to maintain and strengthen the United Nations' capacity to act on the basis of the common interest recognized by the large majority of its members.

Moreover, the position of the Soviet Union may not be frozen for all time. Recently, we have seen some hopeful stirrings in Soviet foreign policy. For various reasons - the confrontation over Cuba, the increase of Western military strength, its split with Communist China, and domestic economic difficulties-the Soviet Union has come to acknowledge and in certain cases to act upon the fact that, despite national and ideological conflicts, nations may share common interests in survival and welfare.

With this modification in Soviet attitudes, there has developed what some have described as a "limited adversary relationship" between ourselves and the Soviet Union-a relationship in which fundamental differences remain but do not preclude limited forms of cooperation based on mutual restraints and reciprocal undertakings that serve the national interests of both sides. Among the more significant manifestations of this new relationship have been the agreements that have helped somewhat to slow down the arms race-the partial ban on nuclear testing, the communications link between Washington and Moscow to help prevent accidental war, and the General Assembly resolution against the placing of weapons of mass destruction in outer space. Other examples have been the agreements on international cooperation in the peaceful uses of outer space and the policy of mutual example in which both countries have announced cutbacks in the production of nuclear materials.

There have also been some straws in the wind on Soviet policy toward the United Nations-the fact that the Soviet Union invited U Thant to Moscow for the signing of the test ban treaty, that it concurred in the application to large nuclear reactors of the safeguards system of the International Atomic Energy Agency, that it has made special efforts at some recent U.N. meetings to avoid polemics and facilitate the orderly disposition of major issues, and that it voted affirmatively in the Security Council on the resolution establishing the U.N. peacekeeping force in Cyprus. We have been disappointed too often in the past to assume that these are more than tactical shifts. Whether they really herald fundamental changes in attitude, only time will tell.

Certainly, there was much in what Khrushchev was saying in 1964 that sounded unusually congenial to American ears. The most celebrated example was his advice to Hungarian comrades that goulash and ballet were more important than revolution. Less widely quoted, but no less interesting, were some of the observations in his message to foreign heads of state at the beginning of the year. Among other things, Khrushchev noted that in our interdependent world, "a collision which may occur in any place and would, seemingly, have a purely local character, can quickly involve many other countries." To avoid the danger of such "collisions," Chairman Khrushchev proposed the conclusion of a treaty for the peaceful settlement of territorial disputes. In explaining this proposal, the Soviet leader appeared to modify somewhat the line that Soviet delegates had been taking in the disarmament negotiations- 
that the problem of peace could be solved automatically by general and complete disarmament without the concomitant improvement of peacekeeping machinery. He asserted that measures of peaceful settlement would make it "far easier" to make progress in disarmament: $:^{5}$

In conditions in which states will no longer have to worry about their frontiers and in which any plans for changing these frontiers by force are banned by international law, many of the motives by which the states were guided in increasing their armed forces must disappear.

Chairman Khrushchev's New Year's Message also had some sympathetic and moderate things to say about the United Nations: ${ }^{6}$

A peaceful settlement of territorial disputes is also favored by the fact that in the practice of international relations there already exists a store of improved methods of peaceful settlement of outstanding issues-direct negotiations between the states concerned, use of good offices, request of assistance from international organizations, and so on. Although in my opinion the United Nations in its present form is far from being an ideal instrument of peaceful cooperation of states, even this organization, granted an impartial approach, can make a positive contribution to the cause of peaceful settlement of territorial and border issues.

This theme was developed further by the Soviet Union in a note sent in July Ig64 to the United States and other U.N. members. The note went beyond the specific reference to territorial disputes in the New Year's Message and urged "wider use ... of the peaceful means of settling international disputes provided for in the Charter." It said an "understanding" among U.N. members on "the strengthening of the organization's effectiveness in safeguarding international peace and security" would "help in further easing international tension, in strengthening mutual trust in relations between States and in normalizing the international situation." In stressing the potential contribution of the United Nations to world peace it warned of "certain circles that have no interest in preserving peace" and of "some countries" which are "still endeavoring by force to maintain their dominion over peoples waging the just struggle for freedom and independence." Some observers felt that these last references may have been intended to apply to a certain large Asian power as well as to Soviet adversaries in the West.

For all its interesting preambular language, however, the July note represented no progress from the traditional Soviet line when it came to details. The note restated the old Soviet position that all U.N. peacekeeping must be subject to the exclusive jurisdiction of the Security Council and therefore to great power veto. It also proposed to introduce the Troika into U.N. peacekeeping operations by requiring the participating of contingents from "socialist" as well as Western and uncommitted countries. The note was particularly disappointing since it came as

¿ Chairman Khrushchev's letter to President Johnson, of Dec. 3I, I963, 50 Dep't State Bulz. I58, I63 $(1964)$.

Id. at 162 . 
a response to new peacekeeping proposals handed to the Soviet Union in March by the United States and United Kingdom. It was poorly received by the large majority of U.N. members who are not prepared to surrender the General Assembly's residual powers to initiate peacekeeping operations.

In the face of these developments diplomatic observers could only regard Soviet professions of interest in a stronger U.N. peacekeeping role with continued skepticism. Obviously Soviet expressions of support for the United Nations can only be meaningful if the Soviet Union embraces not merely the principle of peaceful settlement but the machinery for peaceful settlement embodied in the United Nations-and does so in deeds as well as words in application to specific disputes.

In the months ahead, there will be at least two critical tests of Soviet policy in the United Nations-in addition to the outstanding difficulties between us on Cuba, Berlin, and Southeast Asia. The first test will come in the constitutional crisis that has been precipitated by the refusal of the Soviet Union to pay its dues for U.N. peacekeeping operations. The United Nations cannot work to full advantage as an instrument for peaceful settlement of international disputes until its financial crisis is resolved. If the Soviet Union is really concerned about the contribution that peaceful settlement can make to disarmament and the avoidance of war, it will pay its peacekeeping assessments. Equally important, the Soviet financial boycott of the United Nations has become a serious roadblock on the highway to peace. If the new Soviet leadership seriously wishes to consolidate recent progress toward the relaxation of tensions, it will get off the collision course in the United Nations and avoid a bitter dispute over its voting rights in the Assembly which could set back not only cooperation in the United Nations but the whole climate of international relations.

The second major test of Soviet policy will come in the current re-examination by U.N. members of procedures for initiating and financing future peacekeeping operations. The improvement of present procedures could serve the interests of all members of the United Nations. The members of the United Nations will never accept the Soviet Union's traditional position that no peacekeeping operation can ever take place without its consent, but they might accept adaptations in General Assembly procedures to give large and middle powers a greater voice than they have under present arrangements. Here again, if the Soviet Union is genuinely concerned to improve the international climate and strengthen the machinery of peaceful settlement, it will join with other members in developing rational decision-making procedures for future U.N. peacekeeping operations.

How will the Soviet Union respond to these and other tests of its U.N. policy? Seasoned diplomats and Kremlinologists, recalling past shifts in Soviet policy and innumerable disappointments of previous expectations, will be properly skeptical of the possibilities. We shall have to wait and see.

Yet there is one factor that gives us the right to be hopeful for the long run. 
Soviet foreign policy ultimately reflects Soviet national interest-and the real longterm interest of the Soviet Union, as well as of other countries, would be served by a stronger U.N. that could help the great powers disengage from dangerous confrontations and prevent brush-fire conflicts between small states from triggering a nuclear war. By "real long-term interest," of course, we mean the interest of the Soviet state and people and not the interest of an elite in promoting world Communism by force. The Soviet Union will play a more constructive role in the United Nations only as the former interest takes precedence over the latter.

As Secretary of State Dean Rusk pointed out in his Hammarskjöld Lecture at Columbia University: ${ }^{7}$

As long as a member possessing great power was intent on promoting conflict and upheaval-the better to coerce the world into its own image-that member might well regard the United Nations as a threat to its own ambitions.

But suppose it is agreed that all members, despite their deep differences, share a common interest in survival-and therefore a common interest in preventing resort to force anywhere in the world. Then the peacekeeping capacity of the United Nations can be seen realistically for what it is: an indispensable service potentially in the national interest of all members-in the common interest of even rival states.

${ }^{7}$ Dag Hammarskjöld Memorial Lecture, prepared for delivery by Secretary of State Dean Rusk, and read by Harlan Cleveland, Assistant Secretary for International Affairs, at Columbia University, New York, N.Y., on Jan. Io, I964. 5o Dep't StATE. Bull. II2, II6 (1964). 